\title{
Analisis Iklim Ekstrim untuk Deteksi Perubahan Iklim di Sumatera Barat
}

\author{
Sugeng Nugroho ${ }^{1,4}$, Rudi Febriamansyah², Eri Gas Ekaputra², dan Dodo Gunawan ${ }^{3}$
}

1Mahasiswa Doktoral, Program Studi Ilmu Pertanian, Pascasarjana, Unand; email: sugeng_ho@yahoo.com. 2Program Studi Ilmu Pertanian, Pascasarjana, Unand.

3Pusat Perubahan Iklim dan Kualitas Udara, BMKG.

${ }^{4}$ Stasiun Klimatologi Padang Pariaman, BMKG Sumatera Barat.

\begin{abstract}
ABSTRAK
Konsekuensi signifikandari pemanasan global akibat terjadinya perubahan iklim, yang ditandai dengan meningkatnya kejadian-kejadian iklim ekstrim, baik magnitude maupun frekuensinya. Perubahan iklim yang terjadi pada suatu wilayah sangat tergantung sensitivitas faktor lokal dalam merespon perubahan iklim global yang terjadi. Penelitian dilakukan di wilayah Sumatera Barat yang dibedakan menjadi dua bagian topografi, dataran rendah dan dataran tinggi, dengan menggunakan data observasi dan data model. Indeks iklim ekstrim ditentukan dengan menggunkan standard ETCCDI. Perubahan iklim yang terjadi juga dilihat dari pergeseran pola iklim dalam periode waktu yang telah ditentukan. Signifikansi dari trend iklim ekstrim dan perubahan iklim dilakukan dengan uji Mann-Kendall. Hasil analisis menunjukan secara umum telah terjadi kenaikan suhu udara di wilayah penelitian, baik di wilayah dataran tinggi maupun dataran rendah terdapat kecenderungan peningkatan curah hujan ekstrim di wilayah dataran tinggi, sementara untuk di wilayah dataran rendah cenderung mengalami trend negative. Hasil uji trend menunjukkan bahwa tidak semua variasi trend indek iklim ekstrim signifikan pada uji signifikansi pada tingkat kepercayaan $90 \%$ dan 95\% atau lebih dan juga tidak ada perbedaan kondisi iklim ekstrim antara wilayah dataran rendah dan wilayah dataran tinggi. Pergeseran pola suhu sebesar 0.5 hingga $1.0{ }^{\circ} \mathrm{C}$ baik di daerah dataran rendah maupun tinggi wilayah penelitian.Sedangkan untuk pola hujan terjadi pergeseran dengan rata-rata yang lebih rendah untuk di daerah dataran rendah wilayah penelitian dan kecenderungan terjadinya peningkatan jumlah curah hujan di daerah dataran tinggi wilayah penelitian.
\end{abstract}

Kata kunci : iklim ekstrim, ETCCDMI, pergeseran pola iklim, Sumatera Barat

\begin{abstract}
Significant consequences of global warming due to climate change, which is characterized by increasing extremes of climate events, both magnitude and frequency. Climate change that occurs in an area is highly dependent on the sensitivity of local factors in responding to global climate change that occurred. The research was conducted in West Sumatera region which was divided into two parts of topography, lowland and highlands, using observation data and model data. The extreme climate index is determined by using the ETCCDI standard. Climate change is also seen from the shift in climate patterns within a predetermined period of time. The significance of extreme climatic trends and climate change is done by the Mann-Kendall test. The result of the analysis shows that in general there has been an increase in air temperature in the research area, both in highland and lowland areas there is a tendency to increase extreme rainfall in highland areas, while for lowland areas tend to experience a negative trend. Trend test results show that not all variations of extreme climate index trends are significant on significance tests at $90 \%$ and $95 \%$ or more confidence levels and there is also no difference in extreme climatic conditions between lowland and upland areas. Temperature pattern shift of 0.5 to $1.0^{\circ} \mathrm{C}$ in both low and high areas of research. As for the pattern of rain occurred shift with lower average for in lowland area of research area and tendency of increasing amount of rainfall in highland area of research area.
\end{abstract}

Keywords: extreme climate, ETCCDMI, climate pattern shift, West Sumatra

Citation: Nugroho, S., Rudi, F., Erigas, E., dan Dodo, G. (2019). Analisis Iklim Ekstrim Untuk Untuk Deteksi Perubahan Iklim di Sumatera Barat. Jurnal Ilmu Lingkungan, 17(1), 7-14, doi:10.14710/jil.17.1.7-14

\section{Pendahuluan}

Konsekuensi signifikan dari pemanasan global akibatmeningkatnya konsentrasi gas rumah kaca di atmosfer adalah terjadinya perubahan iklim, yang diantaranya ditandai dengan meningkatnya kejadian-kejadian iklim ekstrim, baik magnitude maupun frekuensinya. Peningkatan iklim ekstrim khususnya temperatur udara dan curah hujan diduga akan semakin menguat sebagai akibat perubahan iklim perlu 
mendapatkan perhatian yang lebih serius karena dampaknya akan berpengaruh terhadap aktivitas manusia dan ekosistem alam (Griffiths and Bradley, 2007; Klein Tank dkk, 2006). Dengan demikian pemahaman tentang iklim ektrim perlu terus dikembangkan, seiring dengan semakin seringnya kejadian-kejadian iklim ekstrim.

Hasil penelitian Endo, dkk (2009) tentang trend curah hujan ekstrim di kawasan asia Tenggara menujukan terjadinya trend penurunan jumlah curah hujan tahunan di Miyanmar, Thailan dan Vietnam bagian utara, sebaliknya peningkatan terjadi di Vietnam bagian selatan dan kepulaun Luzon di Filipina. Penelitian lebih detil tentang hujan ekstrim di Thailan dilakukan oleh Limsakul dan Singruck (2016), menunjukan bahwa curah hujan ekstrim di Thailand dipengaruhi oleh fenomena sirkulasi iklim sekala global di Samudera Pasifik, seperti El Nino Southern Oscillation (ENSO) dan Pacific Decadal Oscillation (PDO). Penelitian curah hujan ektrim di Vietnam juga di lakukan oleh Khoi dan Trang (2016) khususnya di kota Ho Chi Minh yang menyimpulkan terjadinya peningkatan secara signifikan jumlah curah hujan tahunan di bagian barat laut dari kota Ho Chi Minh dan kejadian sebaliknya terjadi di sebelah tenggara kota.

Pengaruh faktor regional dan lokal, seperti sirkulasi siklonik dan topografi terhadap iklim ekstrim juga perlu dipertimbangkan.Seperti halnya iklim ekstrim di bagian barat daya Cina, bahwa peningkatan curah hujan ekstrim di dataran tinggi merupakan hal yang masih semu, sedangkan peningkatan curah hujan ektrim secara nyata terjadi di dataran rendah wilayah tersebut (Zongxing dkk, 2012).

Wilayah Sumatea Barat mempunyai pola iklim yang unik, terbentuk dari adanya interaksi antara sistem sirkulasi atmosfer yang bergerak di atas dengan kondisi topo-fisiografi (bentuk medan) wilayah tersebut yang sedemikian rupa, sehingga menyebabkan lokasi yang terletak dilereng pegunungan yang menghadap ke barat (daerah tangkapan hujan) akan memperoleh curah hujan yang lebih banyak, sementara tempat yang terletak dibalik bukit (daerah bayangan hujan), memperoleh hujan yang paling sedikit (Sandy, 1987). Lokasi-lokasi yang termasuk dalam daerah tangkapan hujan pada umumnya tidak mempunyai kejelasan antara musim kemarau dan penghujan, berbeda dengan daerah tangkapan hujan mempunyai perbedaan antara musim kemaru dan penghujan.Berdasarkan pola iklim wilayah Sumatera Barat yang unik tersebut, penelitian ini bertujuan untuk mendeteksi terjadinya perubahan iklim di wilayah Sumatera Barat berdasarkan pada indeks-indeks iklim ekstrim yang terjadi di wilayah tersebut.

\section{Metode}

\subsection{Wilayah Penelitian}

Penelitian akan dilakukan di wilayah Sumatera Barat. Untuk tujuan deteksi dan proyeksi perubahan iklim, wilayah Sumatera Barat akan dibagi menjadi wilayah dataran rendah dan dataran tinggi. Wilayah dataran rendah akan diwakili dengan data pengamatan di Teluk Bayur (TLB), Tabing (TAB) dan Sicincin (SCN). Sementara Padang Panjang (PPJ) dan Bukit Kototabang (BKT) mewakili data iklim di wilayah dataran tinggi (Gambar 1).Lokasi-lokasi tersebut dipilih untuk analisis deteksi perubahan iklim karena mempunyai pengamatan iklim (curah hujan, suhu maksimum dan minimum) selama 20 hingga 30 tahun terakhir (Tabel 1).

Teluk Bayur terletak di wilayah pantai barat Sumatera Barat, berlokasi di pelabuhan maritim yang sibuk dengan bongkar muat kapal, merupakan daerah urban yang berkembang dengan dinamis. Tabing merupakan bandara udara Sumatera Barat, sebelum pindah ke Ketaping pada tahun 2012. Walaupun tidak terletak di pantai, namun sirkulasi angin darat-laut sangat terasa di lokasi ini dengan lingkungan urban yang selalu ramai akan aktivitas perekonomian masyarakat di kota Padang. Sicincin merupakan daerah suburban dengan perkembangan wilayah yang dapat dikategorikan lambat, di lokasi ini pola sirkulasi angin darat-laut mempengaruhi pola angin harian.Padang Panjang terletak di lereng gugusan gunung Tandikat-Singgalang, walaupun termasuk dalam kategori wilayah urban, perkembangan wilayah Padang Panjang juga dapat dikategorikan lambat.Pola angin harian yang terbentuk lebih dipengaruhi oleh sirkulasi angin gununglembah.Lokasi pengamatan Bukit Kototabang merupakan daerah remote, teletak di atas perbukitan dengan lingkungan dominan berupa vegetasi hutan hujan tropis Bukit Barisan.

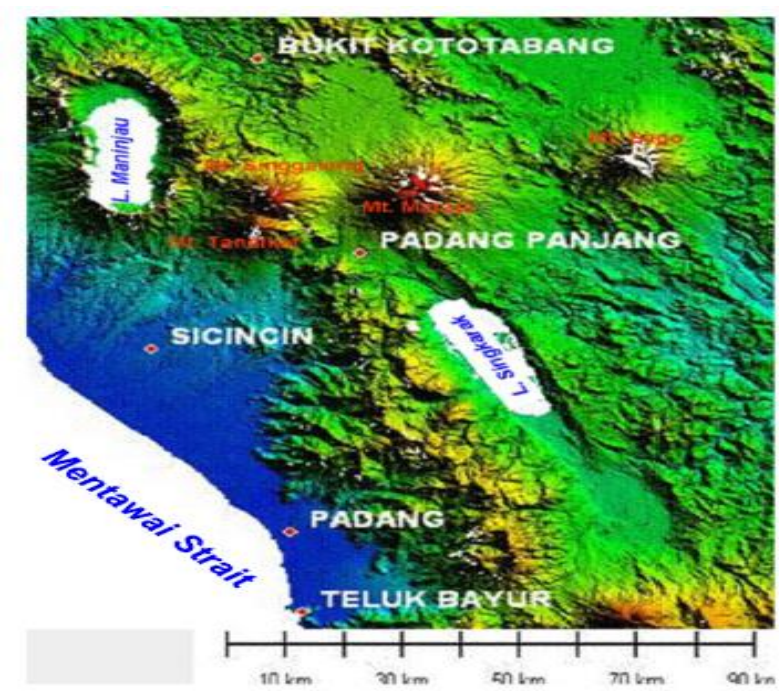

Gambar 1. Wilayah Penelitian (sumber: citra SRTM,) 


\subsection{Pengolahan Data}

Data yang akan digunakan dalam penelitian ini berupa data iklim yang digunakan untuk mendeteksi perubahan iklim yang pada dasarnya merupakan data-data observasi, berupa data hujan, suhu udara maksimum dan minimum harian bersumber dari BMKG Sumatera Barat. Sebagian data tersebut dapat diakses di website dataonline.bmkg.go.id.

Sebelum dilakukan pengolahan indeks iklim ekstrim lebih lanjut, dilakukan terlebih dahulu uji homogenitas terhadap data data iklim dari masing-masing lokasi pengamatan.Terdapat beberapa metode statistik untuk menguji homogenitas suatu series data hujan. Pada penelitian ini akan digunakan paket software RHtest_dlyPrcp. Paket software berbahasa R ini sebenarnya merupakan satu rangkaian paket software untuk mendeteksi dan monitoring iklim ekstrim yang dapat mendeteksi dan melakukan penyesuaian-penyesuaian (adjusment) pada beberapa beberapa titik-titik perubahan (changepoints) yang mungkin ada pada sebuah series data. Pada paket software Rhtest_dlyPrcp terdapat menu Quantile-Matching (QM) adjustments, pada dasarnya digunakan untuk penyesuaian series data sehingga distribusi empiris dari semua segmen yang berbasis detrend akan cocok satu dengan yang lain, dimana nilai adjustmen tergantung pada frekuensi empiris dari datum series data yang di-adjust. (Wang, X. L dan Feng, Y, 2013).

Tabel 1. Diskripsi Lokasi Pengamatan dan Ketersediaan Data

\begin{tabular}{|l|c|c|c|c|c|c|c|}
\hline \multirow{2}{*}{ Lokasi } & Lon & Lat & $\begin{array}{c}\text { Elev } \\
(\mathrm{mdpl})\end{array}$ & $\begin{array}{c}\text { Lingkungan } \\
\text { dominan }\end{array}$ & Topografi & Periode Data \\
\hline BKT & 100.320 & -0.200 & 865 & Remote area & Dataran tinggi & 1997 \\
\hline PPJ & 100.416 & -0.471 & 783 & Urban & Dataran tinggi & 1991 \\
\hline SCN & 100.267 & -0.567 & 137 & Sub-urban & Dataran rendah & 1985 \\
\hline TAB & 100.362 & -0.874 & 3 & Urban & Dataran rendah & 1982 \\
\hline TLB & 100.072 & -1.101 & 2 & Urban & Dataran rendah & 199 \\
\hline
\end{tabular}

Sumber: Stasiun Klimatologi Padang Pariaman dan pengolahan data, 2016

\subsection{Indeks Iklim Ekstrim}

Salah satu indikasi dari dampak perubahan iklim tersebut adalah adanya perubahan pola dan intensitas berbagai parameter iklim diantaranya terjadinya curah hujan yang tidak menentu, intensitas yang cenderung meningkat dan pergeseran awal serta panjang musim yang menyimpang atau ekstrim dibandingkan kondisi normalnya. Variasi rataan dan nilai ekstrim dari suatu variabel iklim yang mempunyai distrbusi stastistik secara baik dapat digunakan untuk mengkarakteristik perubahan iklim yang digambarkan dengan indeks-indeks yang sesuai.Indeks iklim ekstrim yang digunakan pada umumnya berhubungan dengan curah hujan dan suhu udara.Banyak penelitian menggunakan indeks iklim ekstrim dengan menggunakan standar Expert Team on Climate Change Detection, Monitoring and Indices (ETCCDMI). (Alexander dkk, 2006; Zhang dkk, 2011; Donat dkk, 2014).

Untuk mendeteksi terjadinya perubahan iklim di wilayah Sumatera Barat akan digunakan beberapa indeks iklim ekstrim dari ETCCDMI, yang dikelompokan kedalam kategori indek intensitas, durasi dan frekuensi. Untuk variabel suhu udara diantaranya adalah : trend suhu udara maksimum, suhu udara minimum, diurnal temperature range (DTR) yang masuk kedalam kategori indek intensitas suhu udara. Indek kecenderungan jumlah hari hangat atau dingin di siang dan malam hari yang dikategorikan sebagai indek frekuensi suhu udara ekstrim. Untuk indek curah hujan ekstrim yang digunakan antara lain : jumlah hari tanpa hujan berturutan terpanjang
(CDD) dan jumlah hari hujan berturutan terpanjang (CWD) untuk kategori durasi indek hujan ekstrim, hujan dengan intensitas lebih dari 100 milimeter per hari atau lebih (R100) untuk kategori frekuensi indek hujan ekstrim. Jumlah hujan maksimum satu hari (RX1D) dan jumlah hujan maksimum selama lima hari berturutan (RX5D) untuk kategori intensitas indek hujan ekstrim. Daftar lengkap indek iklim ekstrim ETCCDI yang digunakan dalam penelitian ini seperti tercantum pada Tabel. 2.

Perhitungan indek iklim ekstrim akan ditentukan dengan menggunakan software RClimDex, sebuah package software berbahasa $\mathrm{R}$ yang dikembangkan oleh Climate Research Branch of Meteorological Service of Canada untuk kepentingan ETCCDMI guna mendeteksi dan monitoring perubahan iklim dengan fokus utama pada kejadian-kejadian iklim ekstrim (Zhang and Yang, 2004; Alexander dkk, 2006). Signifikasi dari trend akan digunakan metode statistik Mann Kendall test digunakan untuk menghitung trend dari indeks-indeks iklim ekstrim.(Salmi dkk, 2002; Dashkhuu dkk, 2015; Giacone dkk, 2015)

\subsection{Pergeseran Pola Iklim}

Mengacu pada definisi perubahan iklim, yaitu berubahnya parameter-parameter iklim (curah hujan dan suhu) secara statistik dalam interval waktu decade atau periode waktu tertentu.Dimana perubahan parameter iklim tersebut salah satunya ditunjukan oleh adanya pergeseran nilai rataan, sebagai bentuk dari ukuran pemusatan dan penyebaran nilai secara 
statistik (Tarmana, 2014). Untuk melihat pergeseran iklim teresebut, dalam penelitian ini digunakan rumusan statistik: rata-rata untuk mengetahui pergeseran pemusatan data dan presentil ke-10 dan ke-90 sebagai representasi dari pergeseran persebaran datanya dalam kelompok data yang telah dikelompokkan setiap periode waktu tertentu (dekade) di masingmasing lokasi pengamatan, yaitu periode 19811990, periode 1991-2000, periode 20012010,dan periode 2011-2015.

\section{Hasil dan Pembahasan}

\subsection{Trend Indeks Iklim Ekstrim}

\subsubsection{Indeks Suhu Udara Ekstrim}

Hasil pengolahan data indek suhu udara ekstrim seperti terlihat pada Tabel 3a.Indek suhu udara ekstrim dengan kategori intensitas (TXX, TNx, TXn, TNx dan DTR) secara umum menunjukan trend positif, baik di wilayah dataran rendah maupun dataran tinggi, yang secara keseluruhan menandakan terjadinya kenaikan suhu udara di wilayah penelitian.

Indek $\mathrm{TNx}$ terlihat paling menonjol, dimana untuk semua lokasi pengamatan menunjukan kenaikan, dengan trend yang signifikan di BKT, TAB dan TLB.Trend indek TNx yang bernilai positif mengindikasikan terjadinya kenaikan suhu udara minimum paling maksimum. Hal yang sama secara umum juga terjadi untuk indek TXn juga menunjukan trend positif, dengan trend signifikan terjadi di BKT, SCN dan TLB. Trend positif indek TXn menunjukan terjadinya kenaikan suhu udara maksimum paling minimum.

Indek suhu udara ekstrim kategori frekuensi suhu udara ekstrim (TN10p, TX10, TN90p dan TX90p) di wilayah penelitian menunjukan: terjadinya trend negatif untuk indek TN10p dan TX10p sementara trend positif terjadi untuk indek TN90p dan TX90p, baik di wilayah dataran rendah maupun dataran tinggi. Penurunan trend indek TN10p terjadi di semua lokasi penelitian kecuali TLB, dengan trend signifikan terjadi di BKT, SCN dan TAB. Trend negatif dari indek TN10p atau cool nights berarti ada kecenderungan terjadinya kenaikan suhu suhu udara minimum, sehingga secara harfiah dirasakan suhu udara yang semakin hangat pada malam hari. Penurunan trend juga terjadi untuk indek TX10p, dengan trend signifikan terjadi di semua lokasi pengamatan, kecuali BKT. Trend negatif dari indek TX10p atau cool days menunjukan adanya kecenderungan kenaikan suhu udara maksimum sehingga akan dirasakan adanya suhu udara yang semakin hangat pada siang hari.

Tabel 2. Indek Iklim Ekstrim ETCCDMI yang digunakan dalam penelitian

\begin{tabular}{|c|c|c|c|}
\hline \multicolumn{2}{|r|}{ Indek } & \multirow[b]{2}{*}{ Keterangan } & \multirow[b]{2}{*}{ Satuan } \\
\hline \multicolumn{2}{|r|}{ Intensitas } & & \\
\hline $\mathrm{TXX}$ & $\operatorname{Max} \operatorname{Tmax}$ & Suhu maksimum harian tertinggi & ${ }^{\circ} \mathrm{C}$ \\
\hline TNx & Max Tmin & Suhu minimum harian tertinggi & ${ }^{\circ} \mathrm{C}$ \\
\hline TXn & Min Tmax & Suhu maksimum harian terendah & ${ }^{\circ} \mathrm{C}$ \\
\hline TNn & $\operatorname{Min} \operatorname{Tmin}$ & Suhu minimum harian terendah $\quad{ }_{0}$ & ${ }^{\circ} \mathrm{C}$ \\
\hline DTR & Diurnal temperature range & $\begin{array}{l}\text { Suhu rata-rata perbedaan antara suhu udara maksimum dan } \\
\text { minimum harian }\end{array}$ & ${ }^{\mathrm{O}} \mathrm{C}$ \\
\hline \multicolumn{2}{|r|}{ Frekuensi } & & \\
\hline TN10p & Cool nights & Jumlah hari diamana Tmin $<$ persentil ke-10 & $\%$ hari \\
\hline TX10p & Cool days & Jumlah hari diamana Tmax $<$ persentil ke- 10 & $\%$ hari \\
\hline TN90p & Warm nights & Jumlah hari diamana Tmin > persentil ke-90 & $\%$ hari \\
\hline TX90p & Warm days & Jumlah hari diamana Tmax $>$ persentil ke-90 & $\%$ hari \\
\hline \multicolumn{2}{|c|}{ B. Curah Hujan } & & \\
\hline RX1D & Max 1-day precipitation & Jumlah hujan maksimum tahuan dalam 1 hari & $\mathrm{mm}$ \\
\hline RX5D & Max 5-day precipitation & Jumlah hujan maksimum tahuan dalam 5 hari berturutan & $\mathrm{mm}$ \\
\hline SDII & Simple daily intensity index & $\begin{array}{l}\text { Jumlah curah hujan tahunan dibagi jumlah hari hujan (hujan } \geq \\
1.0 \mathrm{~mm} \text { ) }\end{array}$ & $\mathrm{mm} / \mathrm{hari}$ \\
\hline R95p & Annual contribution from very wet days & $\begin{array}{l}\text { Jumlah hujan harian } \geq \text { persentil ke } 95 \text { dalam periode satu } \\
\text { tahun }\end{array}$ & $\mathrm{mm}$ \\
\hline R99p & $\begin{array}{l}\text { Annual contribution from extremely } \\
\text { wet days }\end{array}$ & $\begin{array}{l}\text { Jumlah hujan harian } \geq \text { persentil ke } 99 \text { dalam periode satu } \\
\text { tahun }\end{array}$ & $\mathrm{mm}$ \\
\hline \multirow[t]{2}{*}{ PRCPTOT } & Annual contribution from wet days & Jumlah curah hujan tahunan & $\mathrm{mm}$ \\
\hline & Durasi & & \\
\hline CWD & Consecutive wed day & $\begin{array}{l}\text { Jumlah hari hujan berturutan tahunan terpanjang, dengan } \\
\text { jumlah hujan harian } \geq 1.0 \mathrm{~mm}\end{array}$ & hari \\
\hline \multirow[t]{2}{*}{ CDD } & Consecutive dry day & $\begin{array}{l}\text { Jumlah hari tanpa hujan berturutan tahunan terpanjang, } \\
\text { dengan jumlah hujan harian }<1.0 \mathrm{~mm}\end{array}$ & hari \\
\hline & Frekuensi & & \\
\hline R100 & Precipitation above $100 \mathrm{~mm}$ & Jumlah hari hujan tahunan $\geq 100 \mathrm{~mm}$ & hari \\
\hline
\end{tabular}

Sumber : dimodifikasi dari Alexander dkk, 2006; Zhang dkk, 2011; Donat dkk, 2014. 


\subsubsection{Indeks Curah Hujan Ekstrim}

Pada Tabel 3a, juga terlihat trend positif indek TN90p dan TX90p yang berkebalikan dengan trend indek TN10p dan TX10p, memang seharusnya terjadi seperti itu. Trend signifikan indek TN90p atau warm nights terjadi di semua lokasi pengamatan kecuali TLB. Trend positif indek TN90p menunjukan adanya kecenderungan peningkatan suhu udara minimum yang terjadi pada malam hari. Trend yang sama juga terjadi untuk indek TX90p atau warm days, dengan trend signifikan terjadi di PPJ, TAB dan TLB. Trend positif dari indek TX90p mengindikasikan terjadinya kecenderungan kenaikan suhu udara maksimum yang terjadi pada siang hari.Trend positif dari indek TN90p dan TX90p menunjukan adanya kenaikan suhu udara di wilayah penelitian.

Pada Tabel 3b, terlihat hasil pengolahan data indek hujan ekstrim di wilayah penelitian.Indek hujan ekstrim dengan kategori intensitas (RX1D, RX5D, R95p, R99p dan PRCPTOT), secara umum terjadinya trend positif indek ekstrim kategori tersebut di wilayah dataran tinggi, sementara di wilayah dataran rendah ada kecenderungan terjadinya penurunan trend.Dari hasil uji trend menunjukan indek-indek curah hujan ekstrim kategori ini di wilayah dataran tinggi lebih banyak yang signifikan di bandingkan di wilayah dataran rendah.Indek SDII dan PRCPTOT merupakan indek yang paling jelas untuk membandingkan kejadian curah hujan ekstrim di wilayah dataran tinggi dan dataran rendah.Indek SDII yang terjadi di wilayah dataran tinggi (BKT dan PPJ) menunjukan trend positif yang sangat signifikan dibandingkan dengan trend negatif yang terjadi di wilayah dataran rendah (SCN dan TAB). Hal yang sama juga ditunjukan oleh indek PRCPTOT, dimana di BKT dan PPJ terjadi trend positif sedangkan di SCN, TAB dan TLB terjadi yang sebaliknya.

Indek curah hujan ekstrim dengan kategori durasi (CDD dan CWD) tidak menunjukan adanya suatu pola yang jelas pada lokasi pengamatan ataupun perbedaan wilayah ketinggian. Sedangkan indek curah hujan ekstrim kategori frekuensi terjadinya hujan $\geq 100 \mathrm{~mm}$ per hari (R100), terlihat adanya trend positif di wilayah penelitian pada dataran tinggi dan sebaliknya terjadi trend negatif di wilayah dataran rendah walaupun trend tersebut tidak signifikan.

Pada Tabel 3a dan 3b terlihat bahwa indek-indek suhu udara ekstrim mempunyai pola dan signifikansi yang lebih jelas dibandingkan dengan indek-indek curah hujan ekstrim.Hal ini menunjukan perubahan suhu udara direspon dengan lebih baik dibandingkan dengan perubahan curah hujan di wilayah penelitian, baik di wilayah dataran tinggi maupun dataran rendah.

Tabel 3. Indek Iklim Ekstrim Wilayah Sumatera Barat

(a) Indek suhu udara ekstrim

\begin{tabular}{|c|c|c|c|c|c|c|c|c|c|c|}
\hline $\begin{array}{l}\text { Wilayah } \\
\text { Topografi }\end{array}$ & Lokasi & TXx & $\mathrm{TNx}$ & TXn & $\mathrm{TNn}$ & DTR & TN10p & TX10p & TN90p & TX90p \\
\hline \multirow{2}{*}{ Dataran Tinggi } & BKT & -0.11 & $2.28^{* *}$ & $1.68^{*}$ & -1.64 & 0.42 & $-3.22 * *$ & -1.26 & $3.01^{* *}$ & 0.98 \\
\hline & PPJ & $2.05^{* *}$ & 1.01 & 1.08 & 0.16 & 0.72 & -0.96 & $-2.41^{* *}$ & $1.85^{*}$ & $2.45^{* *}$ \\
\hline \multirow{3}{*}{ Dataran Rendah } & SCN & -0.05 & 0.60 & $2.37 * *$ & 1.50 & $-2.77^{* *}$ & $-4.47^{* *}$ & $-2.38^{* *}$ & $4.28^{* *}$ & 0.85 \\
\hline & $\mathrm{TAB}$ & 1.08 & $3.67^{* *}$ & -1.14 & 1.35 & -0.97 & $-2.48^{* *}$ & $-2.18^{* *}$ & $3.98^{* *}$ & $2.92 * *$ \\
\hline & TLB & 1.47 & $1.73^{*}$ & $2.99^{* *}$ & -1.60 & $3.13^{* *}$ & 1.33 & $-4.00^{* *}$ & 0.03 & $3.10^{* *}$ \\
\hline
\end{tabular}

(b) Indek curah hujan ekstrim

\begin{tabular}{|c|c|c|c|c|c|c|c|c|c|c|}
\hline Wilayah Topografi & Lokasi & RX1D & RX5D & R95p & R99p & SDII & PrcpTOT & CDD & CWD & R100 \\
\hline \multirow{2}{*}{ Dataran Tinggi } & BKT & 0.63 & $2.24^{* *}$ & $2.66^{* *}$ & 0.00 & $2.00^{* *}$ & $2.73^{* *}$ & $-1.94 *$ & -1.59 & 0.04 \\
\hline & PPJ & 1.42 & 0.68 & 1.61 & 1.43 & $2.83^{* *}$ & 1.38 & 1.08 & 1.08 & 1.22 \\
\hline \multirow{3}{*}{ Dataran Rendah } & SCN & -1.09 & -1.02 & $-1.73^{*}$ & $-1.92 *$ & -1.17 & $-2.24^{* *}$ & 1.45 & -1.47 & -.137 \\
\hline & $\mathrm{TAB}$ & 0.17 & 0.14 & -0.15 & 0.19 & -1.09 & -1.19 & 1.11 & -0.41 & 0.00 \\
\hline & TLB & 0.48 & 0.59 & 0.00 & -1.10 & 0.25 & -0.82 & -0.68 & 0.14 & 0.37 \\
\hline
\end{tabular}

\subsection{Pergeseran Pola Iklim}

\subsubsection{Pergeseran Pola Suhu Udara Rata-Rata}

Berdasarkan Tabel 4a dan Gambar 2a, pergeseran pola suhu udara di wilayah penelitian adalah sebagai berikut: di daerah dataran rendah wilayah penelitian (TLB, TAB dan SCN), pergeseran pola suhu udara terlhat jelas di Tabing dan Sicincin, sementara di Teluk Bayur pola suhu udara relative sama. Pergeseran rata-rata suhu udara di Tabing dan Sicincin sekitar $0.3^{\circ} \mathrm{C}$ per decade, demikian juga pergeseran nilai persentil ke-10 dan ke-90 yang terus bergeser kearah kanan sekitar $0.3^{\circ} \mathrm{C}$ per dekade, yang berarti terjadi peningkatan suhu udara minimum dan maksimum sebesar nilai tersebut secara konsiten setiap dekade-nya.

Di daerah dataran tinggi wilayah peneltian (PPJ dan BKT) pergeseran terlihat jelas pada terjadi antara periode 1991-2000 ke 20012010 dan pada dua dekade terakhir, yaitu periode 
2001-2010 dan 2011-2015 mempunyai kemiripan pola pemusatan dan persebaran data. Pergeseran nilai rata-rata suhu pada periode tersebut mencapai $0.5^{\circ} \mathrm{C}$ di Padang Panjang dan $1.0^{\circ} \mathrm{C}$ di Bukit Kototabang dan pergeseran nilai persentil ke-10 yang lebih lebar dibandingkan persentil ke-
90, yang berarti terjadi pergeseran nilai suhu minimum sedangkan suhu maksimum relative lebih tetap. Nilai pergeseran suhu udara di daerah dataran tinggi lebih tinggi jika dibandingkan dengan nilai pergeseran di daerah dataran rendah pada periode waktu yang sama.

Tabel 4a. Analisis Statistik Pergeseran Pola Suhu Udara Rata-Rata $\left({ }^{\circ} \mathrm{C}\right)$

\begin{tabular}{|c|c|c|c|c|c|}
\hline \multirow{2}{*}{ Lokasi } & \multirow{2}{*}{ Unsur Statistik } & \multicolumn{4}{|c|}{ Periode Tahun } \\
\hline & & 1981-1990 & 1991-2000 & $2001-2010$ & 2011-2015 \\
\hline \multirow{3}{*}{ TLB } & Rata-Rata & -- & 27.4 & 27.5 & 27.6 \\
\hline & P10 & -- & 26.7 & 26.7 & 26.9 \\
\hline & P90 & -- & 28.2 & 28.2 & 28.4 \\
\hline \multirow{3}{*}{ TAB } & Rata-Rata & 26.0 & 26.3 & 26.6 & 26.7 \\
\hline & $\mathrm{P} 10$ & 25.4 & 25.8 & 26.2 & 26.3 \\
\hline & $\mathrm{P} 90$ & 26.7 & 26.9 & 27.1 & 27.4 \\
\hline \multirow{3}{*}{ SCN } & Rata-Rata & 26.3 & 26.4 & 26.7 & 26.3 \\
\hline & $\mathrm{P} 10$ & 25.5 & 25.8 & 26.2 & 26.3 \\
\hline & P90 & 26.9 & 27.2 & 27.2 & 26.8 \\
\hline \multirow{3}{*}{ PPJ } & Rata-Rata & -- & 22.5 & 23.0 & 22.9 \\
\hline & P10 & -- & 21.5 & 22.6 & 22.3 \\
\hline & $\mathrm{P} 90$ & -- & 23.3 & 23.6 & 23.5 \\
\hline \multirow{3}{*}{$\mathrm{BKT}$} & Rata-Rata & -- & 22.1 & 23.2 & 23.2 \\
\hline & P10 & -- & 21.2 & 22.7 & 22.7 \\
\hline & P90 & -- & 23.0 & 23.8 & 24.0 \\
\hline
\end{tabular}

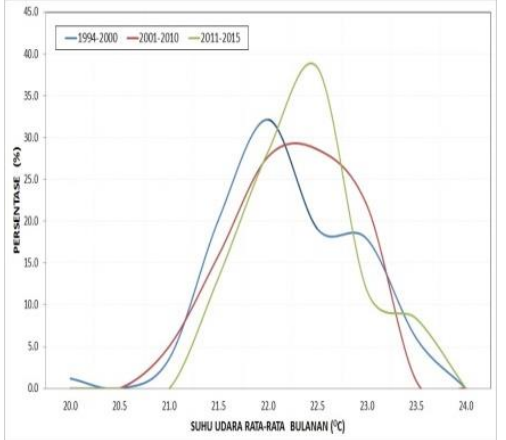

(a) TLB

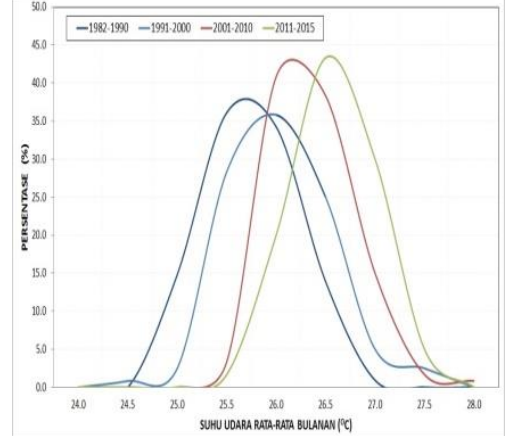

(b) $\mathrm{TAB}$

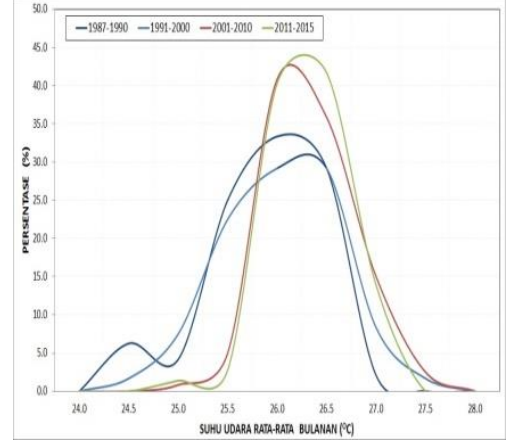

(c) $\mathrm{SCN}$

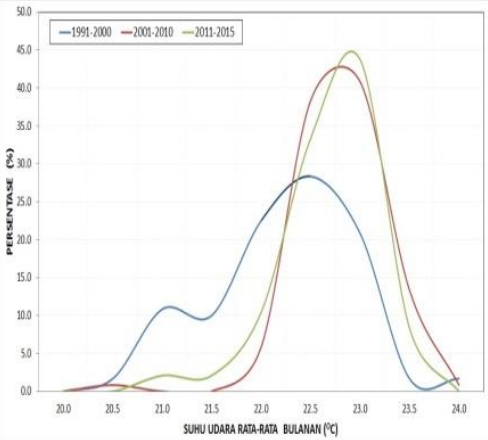

(d) PPJ

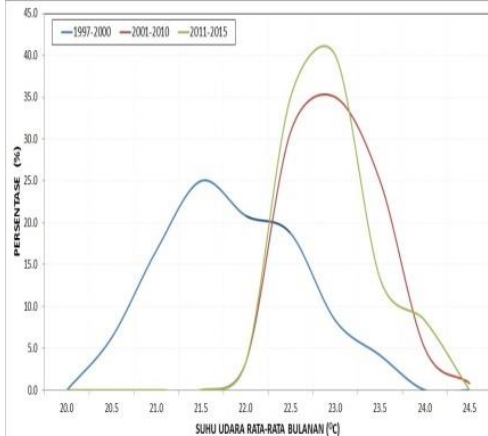

(e) BKT

Gambar 2a. Pergeseran pola suhu udara rata-rata per dekade di wilayah penelitian

\subsubsection{Pergeseran Pola Jumlah Curah Hujan}

Berdasarkan Tabel 4b dan Gambar 2b, di daerah dataran rendah wilayah penelitian terjadinya penurunan nilai rata-rata curah hujan sekitar 10-20 $\mathrm{mm}$ dan pergeseran nilai persentil ke-90 juga mengalami penurunan sebesar 40-70 mm per dekade di Tabing dan Sicincin, kecuali di Teluk Bayur yang tidak terlihat konsistensi penurunannya. Sementara pergeseran nilai persentil ke-10 terlihat mengalami peningkatan walaupun tidak secara konsisten.Hal ini berarti di daerah dataran rendah adanya kecenderungan terakumulasinya curah hujan pada jumlah tertentu pada setiap bulannya, seperti yang terlihat di Teluk Bayur, Tabing dan Sicincin, pada periode waktu dua decade terakhir, curah hujan dengan jumlah 100-200 $\mathrm{mm}$ cenderung mengalami peningkatan frekuensi kejadiannya. 
Pergeseran pola hujan di daerah dataran tinggi terjadi berkebalikan dengan pergeseran pola hujan di daerah dataran rendah. Di daerah dataran tinggi wilayah penelitian, terjadi peningkatan rata-rata jumlah curah hujan sekitar 20-50 mm per dekade, demikian juga untuk nilai persentil ke-10 dan ke-90 yang cenderung mengalami pergeseran kearah kanan sebesar 20$30 \mathrm{~mm}$ per dekade. Hal ini berarti di dataran tinggi wilayah penelitian terjadi kecenderungan peningkatan jumlah curah hujan pada periode waku tersebut.

Tabel 4b. Analisis Statistik Pergeseran Pola Jumlah Curah Hujan Bulanan (millimeter)

\begin{tabular}{|c|c|c|c|c|c|}
\hline \multirow{2}{*}{ Lokasi } & \multirow{2}{*}{ Unsur Statistik } & \multicolumn{4}{|c|}{ Periode Tahun } \\
\hline & & 1981-1990 & $1991-2000$ & $2001-2010$ & 2011-2015 \\
\hline \multirow{3}{*}{ TLB } & Rata-Rata & -- & 344 & 386 & 327 \\
\hline & P10 & -- & 77 & 174 & 128 \\
\hline & $\mathrm{P} 90$ & -- & 597 & 662 & 584 \\
\hline \multirow{3}{*}{$\mathrm{TAB}$} & Rata-Rata & 363 & 344 & 342 & 320 \\
\hline & $\mathrm{P} 10$ & 156 & 100 & 165 & 155 \\
\hline & $\mathrm{P90}$ & 607 & 567 & 563 & 513 \\
\hline \multirow{3}{*}{ SCN } & Rata-Rata & 488 & 378 & 393 & 371 \\
\hline & $\mathrm{P} 10$ & 248 & 147 & 183 & 172 \\
\hline & $\mathrm{P} 90$ & 773 & 600 & 645 & 574 \\
\hline \multirow{3}{*}{ PPJ } & Rata-Rata & -- & 289 & 309 & 335 \\
\hline & $\mathrm{P} 10$ & -- & 98 & 121 & 143 \\
\hline & P90 & -- & 513 & 523 & 569 \\
\hline \multirow{3}{*}{$\mathrm{BKT}$} & Rata-Rata & -- & 164 & 213 & 239 \\
\hline & P10 & -- & 44 & 77 & 90 \\
\hline & P90 & -- & 318 & 396 & 379 \\
\hline
\end{tabular}

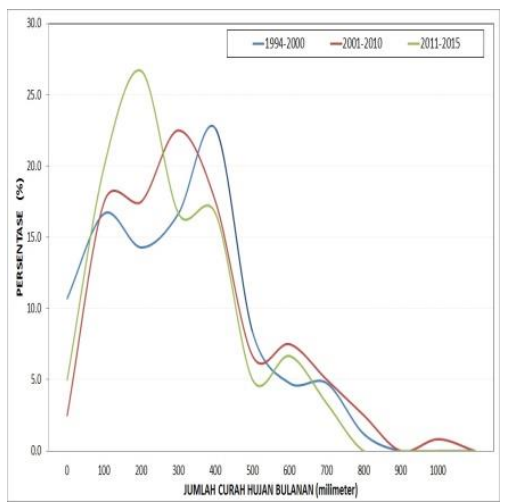

(a) TLB

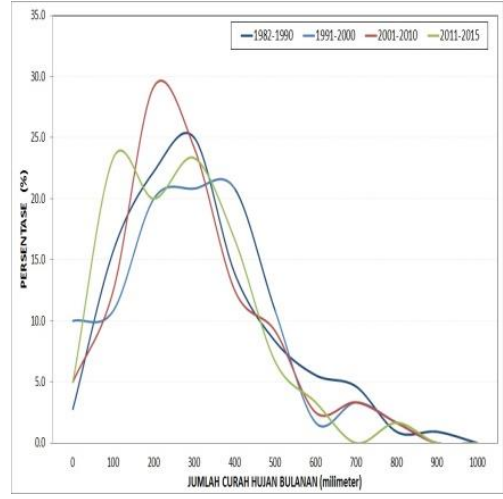

(b) $\mathrm{TAB}$

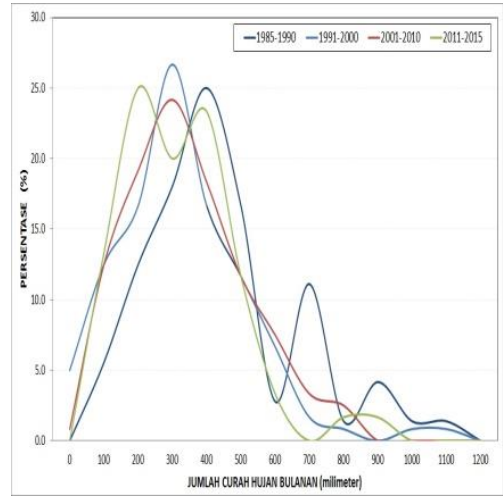

(c) $\mathrm{SCN}$

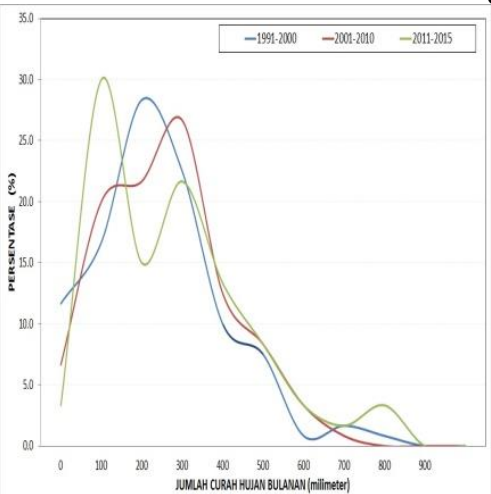

(d) PPJ

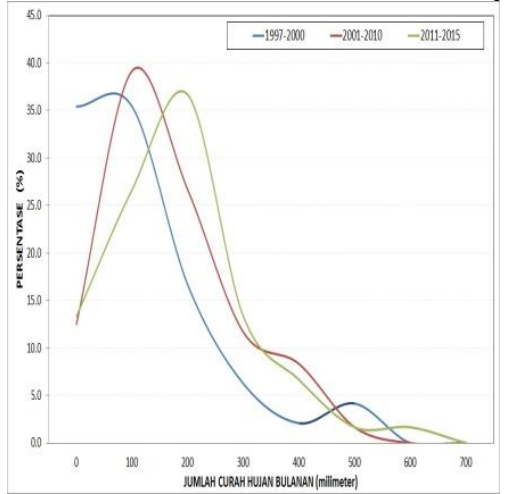

(e) BKT

Gambar 2b. Pergeseran pola jumlah curah hujan bulanan per dekade di wilayah penelitian

\section{Kesimpulan}

Dari hasil analisis dan pembahasan dapat disimpulkan bahwa: secara umum telah terjadi kenaikan suhu udara di wilayah penelitian, baik di wilayah dataran tinggi maupun dataran rendah. Terdapat kecenderungan peningkatan curah hujan ekstrim di wilayah dataran tinggi, sementara untuk di wilayah dataran rendah cenderung mengalami trend negatif.Berdasarkan hasil uji trend dapat diketahui perubahan suhu udara direspon dengan lebih baik dibandingkan dengan perubahan curah hujan di wilayah 
penelitian, baik di wilayah dataran tinggi maupun dataran rendah. Hasil uji trend menunjukkan bahwa tidak semua variasi trend indek iklim ekstrim (temperatur dan curah hujan) signifikan pada uji signifikansi pada tingkat kepercayaan 90\% dan 95\% atau lebih dan juga tidak ada perbedaan kondisi iklim ekstrim antara wilayah dataran rendah dan wilayah dataran tinggi di Sumatera Barat. Pergeseran pola suhu sebesar 0.5 hingga $1.0^{\circ} \mathrm{C}$ baik di daerah dataran rendah maupun tinggi wilayah penelitian. Sedangkan untuk pola hujan terjadi pergeseran dengan ratarata yang lebih rendah untuk di daerah dataran rendah wilayah penelitian dan kecenderungan terjadinya peningkatan jumlah curah hujan di daerah dataran tinggi wilayah penelitian.

\section{DAFTAR PUSTAKA}

A.M.G. Klein Tank, T.C. Peterson, D.A. Quadir, S. Dorji, X. Zhou, H. Tang, K. Santhosh, U.R. Joshi, A.K. Jaswal, R.K. Kolli, A.B. Sikder, N. R. Deshpande, J.V. Revadekar, K. Yeleuova, S. Vandesheva, M. Faleyeva, P. Gomboluudev, K.P. Budhathoki, A. Hussain, M. Afzaal, L. Chandrapala, H. Anvar, D. Amanmurad, V.S. Asanova, P.D. Jones, M.G. New, and T. Spektorman. (2006).Changes in Daily Temperature and Precipitation Extremes in Central and South Asia.Journal of Geophysical Research.111: D16105.

doi: 10.1029/2005JD006316.

Atsamon Limsakul and Patama Singhruk.(2016).Longterm Trend and Variability of Total Extreme Precipitation in Thailand.Atmosphric Research. 169:301-317. doi: 10.1016/j.atmosres.2015.10.015.

Dao Nguyen Khoi and Hoang Thai Trang.(2016).Analysis of Chnages in Precipitation and Extremws Events in Ho Chi Minh City, Vietnam.Procedia Engineerin.142:229-235. doi: 10.1016/j.proeng.2016.02.036.

D. Dashkhuu, J. P. Kim, J. A. Chun, and W.-S. Lee. (2015). Long-term trends in daily temperature extremes over Mongolia.Weather Clim. Extrem. 8:26-33.

E. Giaccone, N. Colombo, F. Acquaotta, L. Paro, and S. Fratianni. (2015). Climate variations in a high altitude Alpine basin and their effects on a glacial environment (Italian Western Alps).Atmósfera. 28(2):117-128.

L. V. Alexander, X. Zhang, T. C. Peterson, J. Caesar, B. Gleason, A. M. G. K. Tank, M. Haylock, D. Collins, B. Trewin, F. Rahimzadeh, A. Tagipour, K. R. Kumar, J. Revadekar, G. Griffiths, and L. Vincent. (2006). Global observed changes in daily climate extremes of temperature and precipitation.Journal of Geophysical Research-Atmospheres. 111: D05109. doi: D0510910.1029/2005jd006290
Li Zongxing, Yuanqing He, Puyu Wang, Wilfred $\mathrm{H}$. Theakstone, Wenling An, Xufeng Wang, Aigang Lu, Wei Zhang, and Weihong Co. (2012).Changes of Daily Extremes in Southwestern China During 1961-2008. Global and Planetary Change.80:255272. doi: 10.106/j.gloplacha.2011.06.008.

M.G. Donat, T.C. Petersen, M. Brunnet, A.D. King, M. Almazroui, R.K. Kolli, Djamel Boucherf, Anwar Yousuf Al-Mulla, Abdourahman Youssouf Nour, Ahmed Attia Aly, Tamer Ali Ali Nada, Muhammad M. Semawi, Hasan Abdullah Al Dashti, Tarek G. Salhab, Khalid I. El Fadli, Mohamed K. Muftah, Sidaty Dah Eida, Wafae Badi, Fatima Driouech, Khalid El rhaz, Mohammed J.Y. Abubaker, Ayman S. Ghulam, Amani Sanhouri Erayah, Mahe Ben Mnsour, Waleed 0. Alabdouli, Jemie Salem Al Dhanhani and Majed N. Al Shekaili. (2014).Change Extreme Temperature and Pricipitation in the Arab Region: Long-term Trend and Variability Related to ENSO and NAO.International Journal of Climatology. 34: 581-592. doi 10.1002/joc.3707.

Michael L. Griffiths and Raymond S. Bradley.(2007).Variations of Twentieth-Century Temperature and Precipitation Extreme Indicators in The Northeast United States.Journal of Climate. 20: 5401-5417. doi: 10.1175/2007JCLI1594.1.

Nobuhiko Endo, Jun Matsumoto, and Tun Lwin.(2009).Trends in Precipitation Extremes over Southeast Asia.SOLA. 5:168-171. doi: 10.2151/sola.2009-043.

Salmi, T., Anu, M., Pia, N., Tuija, R.A., Toni, A. (2002).Detecting Trend of Annual Values of Atmospheric Pollutants by The Mann-Kendall Test and Sen's slope Estimation-The Excel Template Application Makesens.Publications on Air Quality No.31.Finnish Meteorological Institute. Helsinki.

Sandy, I Made. (1987). Iklim Regional Indonesia. Jurusan Geografi,FMIPA, Universitas Indonesia, Jakarta.

Tarmana, D,.(2014).Kapasitas Layanan Informasi Perubahan Iklim BMKG Untuk Sektor Kesehatan dalam Konsep Implementasi Adaptasi Sektoral Perubahan Iklim, Buku Laporan, Deputi Bidang Klimatologi, BMKG.

Xiaolan L. Wang and Yang Feng.(2013).RHtests_dlyPrcp User Manual.Climate Research Division Atmospheric Science and Technology Directorate Science and Technology Branch, Environment Canada Toronto, Ontario, Canada.

X. Zhang and F. Yang.(2004). RClimDex (1.0) User Manual. Clim. Res. Branch Environ. Canada.22: 123.

X. Zhang, L. Alexander, G. C. Hegerl, P. Jones, A. K. Tank, T. C. Peterson, B. Trewin, and F. W. Zwiers. (2011) Indices for monitoring changes in extremes based on daily temperature and precipitation data. Wiley Interdiscip. Rev. Clim. Chang.2(6):851-870. 